\title{
The Development of Lesson Plan Using Blended Learning Model at The University of Billfath
}

\author{
Wilujeng Asih Purwani \\ University of Billfath, Indonesia \\ wilujengasihp@gmail.com \\ Anita Rahmah Dewi \\ University of Billfath, Indonesia \\ anitarahmahdewi92@gmail.com
}

\author{
Article History \\ Received: 08 August 2021 \\ Reviewed: 31 August 2021 \\ Accepted: 09 September 2021 \\ Published: 30 September 2021

\section{Highlights} \\ Blended Learning Lesson Plan \\ design can be applied to Bahasa \\ Inggris II (English for \\ Chemistry) courses.
}

\begin{abstract}
This research is to redesign the Lesson Plan Bahasa Inggris II (English for Chemistry) by using Blended Learning (BL). The purpose of this study is (1) presenting the Blended Learning (BL) learning development process; (2) integrating face-to-face (F2) learning methods with online learning models; and (3) testing the effectiveness of blended learning (BL) in Chemical Education Study Program University of Billfath. The research design used is research and development ( $R \& D$ ) by applying the Addie model with five stages: (1) analyze phase; (2) Design (Design); (3) Development; (4) Implementation; (5) and evaluation (evaluation). The object of the research was the English language course II carried out in the even semester in the Chemical Education Study Program in the Faculty of Teacher Training and Education, University of Billfath. There are two methods in covering blended learning material as outlined in the lesson plan. The expert validity test showed the results, 96\% from Lesson Plan experts, LMS expert 85\%, 88,2\% from English material experts and 86,7\% from Chemistry experts, while $93,2 \%$ from learning media experts and all of them fall into the valid category. Furthermore, the results of this study indicate that $78,54 \%$ this learning gets a valid category from the observer. The implementation of a lesson plan with a blended learning model provides convenience in the learning process. Students have enough time to learn English anytime anywhere with online learning methods and conduct more intensive discussions in face-to-face meetings
\end{abstract}

Keywords: Development, Lesson Plan, Blended Learning.

\section{Introduction}

Learning English at the university level is one of the general compulsory subjects. Although the English course itself is mandatory for all study programs, in reality it is still one of the most difficult courses. The problem in learning English is the use of Tenses/Grammar both in written and spoken language. Another problem is integrating English with the field of science being pursued. Chou (2013) said that English is prepared as a language-use strategy which is an effective approach so that students are able to master four skills; listening, reading, speaking, and writing. Specific English for study programs is included in the English for Specific 
Purposes (ESP) category or English that is designed based on the science being occupied. Therefore, it is necessary to develop a lesson plan / lesson plan that is in accordance with the characteristics of each science.

General compulsory subjects in English courses in the Chemistry Education study program, Faculty of Teacher Training and Education, University Billfath are given in odd and even semesters (semesters 1 and 2). In semester I the English material is designed for general learning (English for General) while the English material in the second semester is designed in learning that is more specific to the study program, in this case English II (English for Chemistry). Learning with specific materials is prepared so that students are able to write and speak in an academic context, Flowerdew (2012) implicit approach is carried out so that students focus on developing more holistic and centered material.

Based on the Lesson Plan that was prepared in the previous year and based on the analysis of student needs in this digital era, there is a need for new developments in the preparation. Taseman, et al., (2020) said that innovative learning strategies are needed in various relevant and interesting ways. Munir (2017: 4) explains that digital learning is a system that can facilitate learners to learn more widely, more and varied without being limited by distance, space and time. The existing lesson plans require modifications that combine fac-to-face (f2f) and online learning, this learning is known as Blended Learning (BL). The concept of Blended Learning (BL) according to Hinkelman (2018) is a combination of face-to-face and online classes, BL is an innovation and technology that is believed to be a process to stimulate learning both physically and virtual.

The blended learning model is expected to be a solution for learning English. The effectiveness of the blended learning method can be realized by designing the lesson plan properly. This blended learning method is important as an English learning strategy for nonEnglish education students. The preparation of the material that has been prepared in the lesson plan with the blended learning model contains two methods, namely face-to-face (f2) and online learning. These two methods will be able to contribute to the effectiveness of language learning. Material that can be presented face-to-face (f2) is material that has been previously discussed online so that students will have more time to study both with the time specified in face-to-face classes and online classes that can be accessed anytime and anywhere.

Blended Learning (BL) is designed so that the learning process and application of digital technology can be implemented optimally in the classroom. Castro (2019) mentions its implementation, firstly by providing access and facilities to students so that online learning activities will be more widely affordable. Second, provide opportunities for each student to improve learning outside the classroom and provide feedback.

The learning process can make it easier for students to learn language science and in this case, brainstorming is very influential on students' critical attitudes in learning. Brainstorming can be done online, where students learn the material independently. Meanwhile, in face-toface classes, students will begin to explore ideas widely, present material critically and use proper pronunciation. Purwani (2021) suggested that presentation has a significance influence for the learning process 


\section{Method}

This research is a research and development (Research \& Development) the researcher uses the ADDIE (Analyze-Designs-Development-Implementation-Evaluation) model from Dick and Carrey to redesign the Lesson Plan in Bahasa Inggris II (English for Chemistry) using the Blended Learning (BL) model. The result at this stage is the development of a Lesson Plan which is then outlined in a blended learning-based textbook. The platform that can be used in online classes is e-learning Billfath.

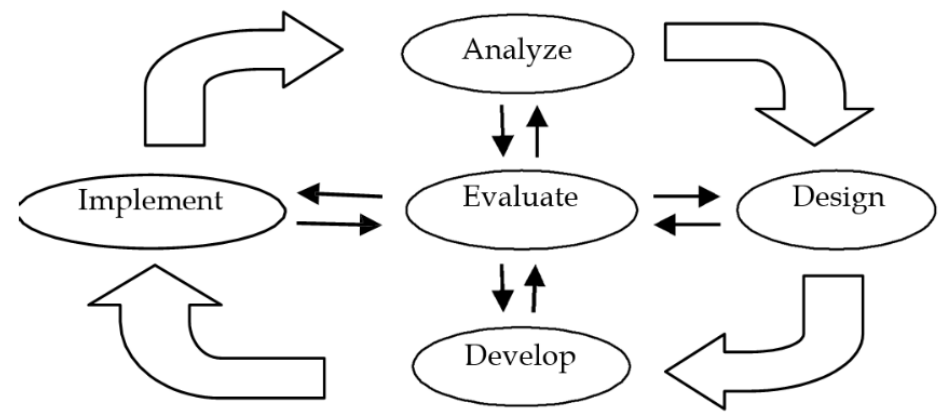

Figure 1: ADDIE Dick and Carey Model (Wibawa \& Harimurti 2017)

This study uses the ADDIE model (figure 1) with five stages: (1) analyze phase; (2) designs; (3) development; (4) implementation; (5) and evaluation. The stages of the ADDIE model in the picture above can be described in the following explanation:

\section{Analyze Phase}

In the needs analysis stage, researchers will look at the competence of Chemistry Education students how their learning process in English courses. At this stage, the characteristics of students in learning English are also seen. This needs analysis can be seen through the pretest. Pretest is held at the beginning of the online meeting

\section{Design}

At the design stage, the researcher designs a learning model that will be delivered by combining face-to-face and online learning models and selecting materials as outlined in the Lesson Plan for Chemistry Education. The material that will be delivered online is the regulation of lecture material at each face-to-face. The reading material has been presented on the billfath e-learning platform so that students can read and understand the content of the material. Then students provide feedback in the form of comments regarding responses or questions on each presented. Feedback given by students will be discussed later in face-to-face meetings so that the class will be interactive because it has been well prepared.

\section{Development}

Development in this case is the material delivered through a blended learning model to achieve learning outcomes. The material has been stated in Lesson Plan which combines faceto-face and online meetings. Lesson Plan is validated by learning device experts, LMS is validated by design experts, Chemistry material experts by Chemistry lecturer and English material expert is validated by English Education lecturer and learning media validated by media expert. Observations during learning are carried out by an observer who assesses the learning process 


\section{Implementation}

The next stage is implementation in Bahasa Inggris (English for Chemistry). The activity begins with face-to-face learning, in this meeting students get an explanation of the learning system that will be implemented for one semester. Namely students reading material provided by the lecturer on the E-Learning platform and students who have programmed Bahasa Inggris II (English for Chemistry) must join the class group. To determine the ability of students at the beginning, a pre-test in the form of writing an essay was conducted. Students collect pre-tests in the form of essays to their respective e-learning accounts. Furthermore, the results of the pretest will be discussed in the face-to-face class.

\section{Evaluation}

At this stage, it will be explained about the implementation of the lesson plan design based on blended learning. The assessment is carried out by one observer and in this case is carried out by an English lecturer at each lecture meeting. The results of each validator use a percentage in the table 1 .

Table 1.

Blended learning eligibility criteria

\begin{tabular}{ccc}
\hline Percentage $(\%)$ & Qualifications & Equivalent \\
\hline $80-100$ & Valid product & Proper \\
$60-79$ & Quite valid product & Quite proper \\
$30-59$ & Not valid product & Less proper \\
$0-29$ & Invalid product & Unproper \\
\hline
\end{tabular}

\section{Findings and Discussion \\ Findings}

The results of the analysis conducted by the lesson plan developer show that blended learning provides great benefits in learning. Face-to-face learning becomes more effective because it has previously been discussed in online discussion classes and lecturers provide feedback in online classes so that students can control the extent of their understanding of the material that has been delivered.

\section{Development}

The product at this stage is a Lesson Plan which contains both online and face-to-face learning methods. The design of this Lesson Plan is in the form of material that has been compiled based on a list of materials presented in the English course for chemistry. The material has been included in the English learning module for chemistry. The result of the development of this lesson plan is in the form of RPS (Rencana Pembelajaran Semester) which is then outlined in the learning module for the English II course. This learning uses an e-learning platform provided by the university. The RPS (Rencana Pembelajaran Semester) contains student learning experiences with face-to-face and online methods. Each material is included based on the category of course learning achievement with structured learning steps

\section{Design}

The design of this learning model is in online meetings the lecturer provides material and conducts questions and answers with students. At face-to-face meetings the lecturer checks each 
student's understanding of the material such as the accuracy of pronunciation, the accuracy of using part of speech, and the accuracy of using English vocabulary in chemistry. Students read the material and provide online feedback and conduct peer evaluations. Furthermore, in faceto-face meetings on Reading material, which is requires understanding and discussion, students form expert groups. Each member presents the material to other groups and each returns to their group. Students carry out discussions again with their groups in order to get a thorough understanding.

\section{Implementation}

The results of the validity test from five experts and also based on observations of blended learning model for Bahasa Inggris II are described in the table 2.

Table 2

The results of the validity test

\begin{tabular}{cccc}
\hline Validator & $\begin{array}{c}\text { Acquisition Score / } \\
\text { Max Score }\end{array}$ & Percentage & Category \\
\hline Lesson Plan expert & 60 & $96 \%$ & Valid \\
Design of LMS expert & 60 & $85 \%$ & Valid \\
Learning Media expert & 44 & $93,2 \%$ & Valid \\
English material expert & 68 & $88,2 \%$ & Valid \\
Chemical material expert & 68 & $86,7 \%$ & Valid \\
Observer & 600 & $78,54 \%$ & Quite Valid \\
\hline
\end{tabular}

Based on the results of the expert validity test and also learning observations, the lesson plan that have been compiled in the Rencana Pembelajaran Semester (RPS) from Lesson Plan expert get $96 \%$ and have been tested on the English II course are included in the valid category. From the expert of Learning Management System (LMS) validation results obtained $85 \%$. The learning media has also been validated by Learning Media Expert and obtained results 93,2\%. In language learning, material is needed that is in accordance with the learning achievements that are charged to the course. Therefore, the English material has been validated by experts and received a score of $88,2 \%$, as well as material in the field of chemistry, from the validation results got $86,7 \%$. Learning in the classroom has passed the observation process and at this stage is carried out by an observer at each lecture session, the results of the validation show that it is quite valid with a score of $78,54 \%$

\section{Discussion}

Lesson Plans or what are called Rencana Proses Pembelajaran (RPP), in higher education are realized in several learning tools, one of which is the Rencana Pembelajaran Semester (RPS). In this study, the lesson plan was rearranged using a blended learning model. At the University of Billfath this method was the first to be used in a Language class. The lesson plan which was originally only for face-to-face learning has now been redesigned with two face-toface and online methods to meet technology-based learning standards. The process of designing a lesson plan is the first step for lecturers in determining the direction of learning and as an effort to increase the effectiveness of the learning process. Rusznyak \& Walton (2011) stated 
Tell : Teaching of English Language and Literature Journal

Vol. 9, No.2, September 2021, Doi: http://dx.doi.org/10.30651/tell.v9i2.9400

that designing lesson plans is an effort to improve professional competence between lecturers and students, therefore lecturers need to increase knowledge of pedagogical content. In line with this thought, Estella \& Alexander (2018) emphasized that lesson plans are made by lecturers based on the learning needs of students and are an important point in teaching and learning activities.

In this study, the lesson plan was developed into three principles in its preparation. As described by the figure 2 below.

\begin{tabular}{|c|c|c|}
\hline $\begin{array}{l}\text { Representation } \\
\text { Principle } 1\end{array}$ & $\begin{array}{l}\text { Action and Expression } \\
\text { Principle } 2\end{array}$ & $\begin{array}{l}\text { Engagement } \\
\text { Principle } 3\end{array}$ \\
\hline $\begin{array}{l}\text { Presenting information and course } \\
\text { content in multiple formats so that } \\
\text { all students can access it }\end{array}$ & $\begin{array}{l}\text { Allowing students alternatives to } \\
\text { express or demonstrate their } \\
\text { learning }\end{array}$ & $\begin{array}{l}\text { Stimulating students' interests and } \\
\text { motivation for learning in a variety } \\
\text { of ways }\end{array}$ \\
\hline $\begin{array}{l}\text { Examples } \\
\text { - Provide alternatives for } \\
\text { accessing information (e.g., } \\
\text { visual, auditory) } \\
\text { - Provide or activate background } \\
\text { knowledge in multiple ways } \\
\text { (e.g., pre-teaching concepts, } \\
\text { using advanced organizers) }\end{array}$ & $\begin{array}{l}\text { Examples } \\
\text { - Provide options for responding } \\
\text { (e.g., keyboard instead of pen to } \\
\text { complete a writing assignment) } \\
\text { - Provide options for completing } \\
\text { assignments using different } \\
\text { media (e.g., text, speech, film, } \\
\text { music) }\end{array}$ & $\begin{array}{l}\text { Examples } \\
\text { - Provide options that increase the } \\
\text { relevance and authenticity of } \\
\text { instructional activities (e.g., } \\
\text { using money to teach math, } \\
\text { culturally significant activities) } \\
\text { - Provide options that encourage } \\
\text { collaboration and } \\
\text { communication (e.g., peer } \\
\text { tutoring) }\end{array}$ \\
\hline
\end{tabular}

Figure 2. Universal Design of Learning, The IRIS Center for Training Enhancement (in Courey \& Tappe, 2012)

Adapted from Universal Design of Learning, The IRIS Center for Training Enhancement (in Courey \& Tappe, 2012), the three principles are; First, the principle of representation, namely the presentation of material that can be accepted by all diverse students, all materials used in learning English II (English for Chemistry) have been adapted to more specific English language needs. This first principle can be realized through written text, videos and demonstrations applied to the course of Bahasa Inggris II. All materials used in learning English II (English for Chemistry) have been adapted to more specific English language needs. Such as material descriptions of laboratory equipment, talking about chemical scientists, types of chemistry and so on, delivered in English. The second principle is action and expression, in this principle students are given the freedom to demonstrate their learning process and results. This can be realized in conversation/discussion using English as well as in the demonstration material for chemical laboratory equipment. The third principle is engagement, on this principle students can do peer tutoring. Peer tutoring is a way for students to learn interactively by teaching/exchanging information with their friends.

Blended Learning (BL) is an innovation designed to meet the needs of learning and teaching. BL is an interactive learning solution by involving each individual in learning. Blended Learning (BL) according to Hockly (2018) is the use of computer technology as part 
of learning that takes place in a certain place in a flexible time. Blended Learning (BL) itself is a combination of cooperative classes (learning in class) and online learning. Thorne (2003) Blended Learning (BL) combines multimedia technology, video, virtual/online classes (virtual classrooms), email and conference calls, online text animation and video streaming.

The design of the Blended Learning (BL) in figure 3, according to Bosc \& Mentz (2019), is a way in an effort to improve student learning processes so that they are maximal in participating in learning activities. Based on the research conducted by Bosc and Mentz, only a few students were unable to adapt to the Blended Learning (BL) learning design. Therefore, researchers use this model design as an implementation in improving student learning of the Chemistry Education Study Program in Bahasa Inggris II (English for Chemistry) courses by integrating aspects of Blended Learning (BL): (1) Electronic learning guides are available on the LMS (Learning Management System), (2) online test activities and provide direct feedback, (3) online discussion forums, (4) interactive online learning, (5) materials provided by lecturers online (e-learning). Pedersen \& Kuran (2018) said that well-organized courses not only help facilitate but are also transparent for all stakeholders (lecturers, students, and administrative systems).

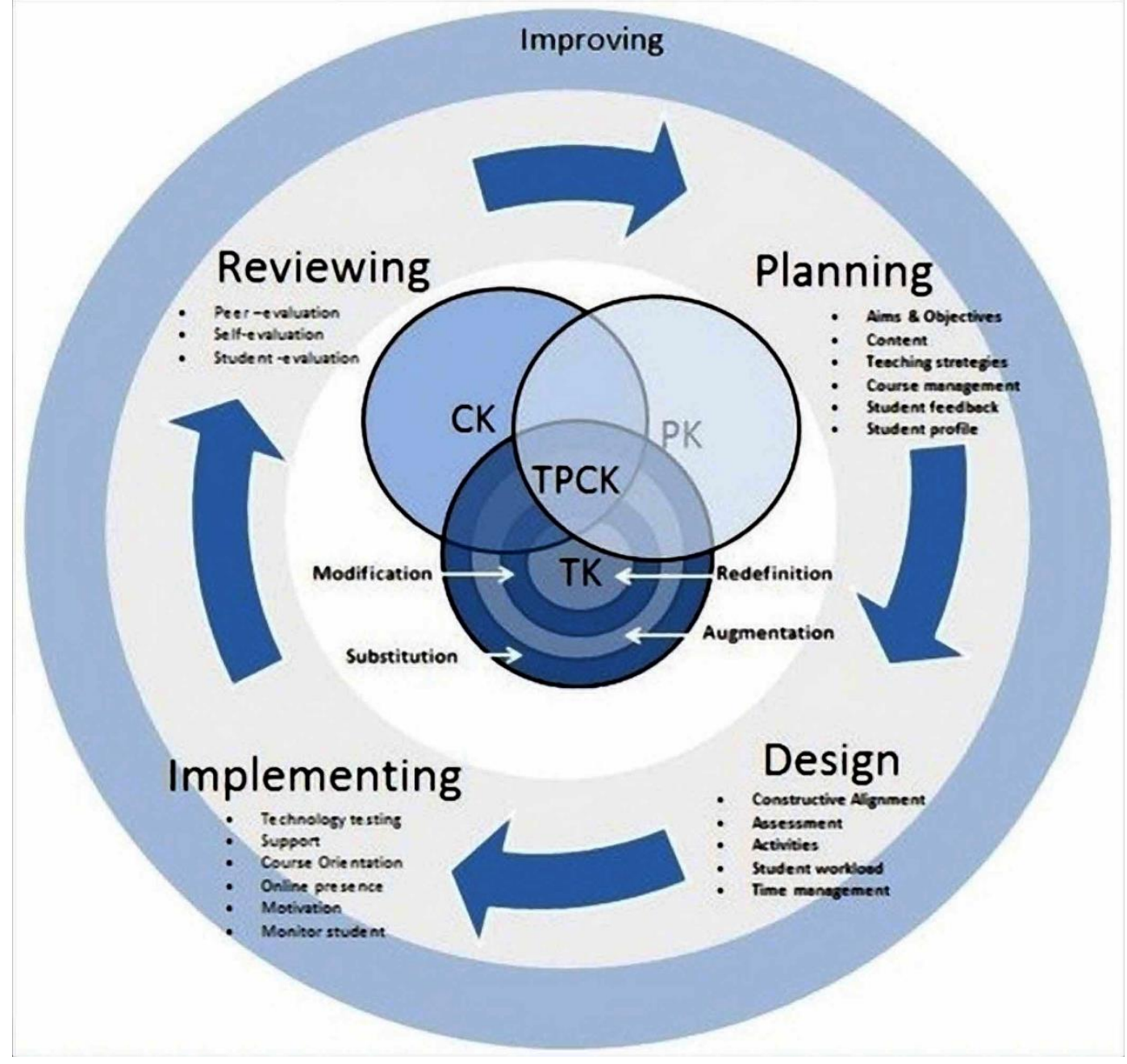

Figure 3. Blended Learning (BL) Design. (Bosc \& Mentz 2019) 


\section{Conclusion}

With the results of the assessment of the validity of the experts and observers in their assessment included in the valid category, the development of the Lesson Plan with this blended learning model can be considered to be applied in English for Chemistry courses. This blended learning is an innovation where lecturers and students have extensive interaction time both online and face-to-face. In language courses, it is not enough to rely on online or face-to-face classes because language courses are skills that are related to one another. Mastery of grammar, writing, speaking, listening, reading is still difficult for non-English students. Therefore, a learning model is needed that is in accordance with the needs of students in learning. For further researchers and developers, it is hoped that they can provide a more varied learning model and find an innovation in the Learning Management System (LMS) to make it easier for lecturers and students to learn English.

\section{References}

Bosch, Chantelle et al. (2019). Integrating Cooperative Learning into the Combined Blended Learning Design Model: Implications for Students' Intrinsic Motivation. International Journal of Mobile and Blended Learning. 58-73.

Castro, Robin. 2019. Blended Learning in Higher Education: Trends and Capabilities. Journal of Springer Nature. https://doi.org/10.1007/s10639-019-09886-3.

Chizik, E.W \& Chizik, A.W. (2018). Using Activity Theory to Examine How Teachers' Lesson Plan Meet Students' Learning Need. Journal of Education Recources Information Center. 67-85. https://doi.org/10.1080/08878730.2017.1296913.

Cou, Mu-hsuan. (2013). Strategi Use for Reading English for General and Specific Academic Purposes in Testing and Nontesting Contexts. Journal of Reading Research Quartely. 175-197.

Courey et al. (2012). Improved Lesson Planning with Universal Design for Learning. Journal of the Teacher Education Division of the Council of Exceptional Children. 7-27.

Flowerdew, Lynne. 2012. Need Analysis and Curriculum Development in ESP. Journal of ESP and Pedagogy. 325-346.

Hinkelman, Don. (2018). Blended Learning. America: John Wiley \& Sons, Inc.

Hockly, Nicky. (2018). Technology for the Languange Teacher: Blended Learning. ELT Journal of Oxford University. 97-101.

Kaeley, Edith. (2010). Assessment and Evaluation in Social Work Education: Formative and Summative Approaches. Journal of Teaching in Social Work. 64-74.

Munir. (2017). Pembelajaran Digital. Bandung: CV. Alfabeta.

Nassaji, Hossein. (2015). Qualitative and Descriptive Research: Data Type Versus Data Analysis. Journal of Language Teaching Research. 129-132.

Purwani, W.A. (2021). Learning Method Using Communicative Approaches to English Grammar Teaching. Journal of KARANGAN. 1-6

Kuran et al. (2018). Learning Management Systems on Blended Learning Courses: An Experience-Based Observation. Conference Paper in Advances in Intelligent Systems and Computing. 1-9. 
Tell : Teaching of English Language and Literature Journal

Vol. 9, No.2, September 2021, Doi: http://dx.doi.org/10.30651/tell.v9i2.9400

Rusznyak, Lee \& Walton, Elizabeth. (2011). Lesson Planning Guidelines for Student Teachers:

A Scaffold for the Development of Pedagogical Content Knlowledge. Journal of Education as Change. 271-285. http://dx.doi.org/10.1080/16823206.2011.619141.

Taseman et al. 2020. Meeting Standards through Integrated Curriculum: Point of View by

Sussan M. Drake and Rebecca C. Burns. Journal of IJORER. 58-62.

Thorne, Kaye. (2013). Blended Learning: How to Integrate Online and Traditional Learning. UK: Kogan Page.

Wibawa \& Harimurti. (2017). The Design and Implementation of An Educational Multimedia Interactive Operation System Using Lectora Inspire. Journal of Elinvo. 74-79.

\section{(ब) $\Theta$}

